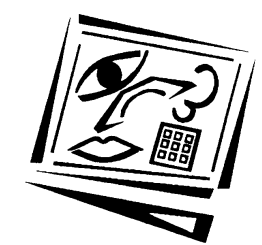

\title{
Self reflection and preservice teachers' technological pedagogical knowledge: Promoting earlier adoption of student-centred pedagogies
}

\author{
Ping Gao, Tan Seng Chee, Longlong Wang, Angela Wong and Doris Choy
} Nanyang Technological University

\begin{abstract}
The purpose of this paper is to present the qualitative findings relating to fourteen preservice teachers' development and translation of their technological pedagogical knowledge (TPK) into their classroom practices throughout the first year of their teacher preparation program. It was found that all fourteen participants demonstrated a gain in both technological and pedagogical knowledge, and registered positive changes both in their pedagogical beliefs and their beliefs in using information and communication technology (ICT) to engage their students in active meaning making after an ICT course and an intervention workshop on reflection. There was, however, great variation in the ways that they used ICT in their first field placements: from using ICT as a presentation tool to complement or support their teaching, to engaging their students in using ICT as a cognitive tool to extend their students' learning and knowledge construction. This variation was largely related to whether the participants could synergise their constructivist-oriented beliefs, technological knowledge and pedagogical knowledge. It seems that only the preservice teachers who demonstrated student-centric pedagogies and reflected on student learning showed more advanced development of TPK. Recommendations for engaging preservice teachers in reflection with a focus on student learning are discussed.
\end{abstract}

\section{Introduction}

This study examines the development and translation of technological pedagogical knowledge (TPK) into their classroom practice among preservice teachers through selfreflection in the early stage of a teacher preparation program. As an important component of technological pedagogical content knowledge (TPACK) that involves a complex blend of teacher knowledge (Mishra \& Koehler, 2006; Harris, Mishra \& Koehler, 2009), technological pedagogical knowledge (TPK) refers to knowledge of the existence, components and capabilities of various technologies as they are used in teaching and learning, and conversely, knowing how teaching might change as the result of using particular technologies (Mishra \& Koehler, 2006). Therefore, it is important for preservice teachers to know what technological tools to use, how to properly use them, and how to make them pedagogically appropriate to the discipline in question. The quantitative evidence shows the effectiveness of the university technology coursework on preservice teachers' development of TPACK (Finger, Jamieson-Proctor \& Albion, 2010; Koh, Chai \& Tsai, 2010; Niess, 2005; Schmidt, et. al., 2009), and qualitative findings also suggest that teachers could develop TPACK in specific course contexts (Mishra \& Koehler, 2006). However, little is known about whether preservice teachers can translate their gained TPK into their classroom practices during their school placements. 
We acknowledge the importance of content knowledge. We have also noted that teachers' lack of TPK is a critical barrier in their use of ICT for classroom teaching and learning (Gao, 2005; Gao, Choy, Wong \& Wu, 2009). For scoping purposes, this study specifically focuses on how preservice teachers translate their technological pedagogical knowledge (TPK) from self-reflection during the coursework and field experience in the first year of their teacher preparation program. We aimed to address the research gap: whether the preservice teachers could translate their increased TPK into classroom practices, while being caught in the midst of conflicting demands and multiple challenges during their field placements (Gao, Choy, Wong \& Wu, 2009). If they could, what contributes most to such a translation?

\section{Related literature}

Three bodies of literature were reviewed for the preparation of this article. The first is related to TPACK, which is based on Shulman's PCK (1987). Shulman (1987) provided an analytic lens for studying the development of teacher knowledge as a complex structure including content knowledge, pedagogical knowledge, and pedagogical content knowledge (PCK). According to Shulman, PCK is a teacher's ability to convey the constructs underlying the elements of the content knowledge in a manner that makes it accessible to students. Extending the framework of PCK, Mishra and Koehler (2006) and Harris, Mishra and Koehler (2009) proposed technological pedagogical content knowledge (TPACK) as an overarching conception of what it means to integrate technology to teach particular content topics with appropriate teaching strategies. Therefore, TPACK is "an analytic lens for studying the development of teacher knowledge about educational technology" (Mishra \& Koehler, 2006, p.1041). However, little in the literature shows us whether preservice teachers could translate their increased TPK into classroom practices.

The second part of the literature reviewed is related to preservice teachers' use of ICT for classroom teaching and learning. There is much to consider for addressing this issue. Firstly, as a result of receiving the fundamental experiences for the use of technology during the preservice teacher preparation, most of preservice teachers possess essential ICT skills and knowledge as well as positive attitudes from their university coursework (Kay, 2006; Swain, 2006). A large body of studies has examined the improvement of preservice teachers' technological knowledge and/or attitudes towards ICT after taking on campus technology courses (see Kay, 2006, for a literature review on this topic). It is further suggested that preservice teachers should apply their learned knowledge from the coursework into authentic teaching experiences (Vannatta, Beyerbach \& Walsh, 2001; Bullock 2004). However, preservice teachers do not appear to be ready for using ICT in their teaching during their field placements (Brown \& Warschauer, 2006). A growing number of studies started exploring preservice teachers' technology field experiences, while some have focused on the factors influencing preservice teachers' decision-making in using ICT in their field placements (Gao, 2005; Bullock, 2004).

Teachers' beliefs on teaching and learning have an impact on their use of ICT (Lim \& Chai, 2008). When teachers hold beliefs that emphasise the importance of the teacher as an efficient means of distributing knowledge, they tend to use ICT for productivity (Maddux, LaMont Johnson \& Willis, 2001), as an opportunity to complement or amplify the existing teaching approaches (Hughes, Thomas \& Scharber, 2006), rather than student learning outcomes. Unless their teacher centric beliefs are challenged, 
they hardly use ICT as an intellectual partner -- ICT is used as a cognitive tool (Jonassen Peck, \& Wilson, 1999) to extend students' learning and creativity. Research evidence indicates that preservice teachers are not cognisant of the complexities of teaching, which interacts with technology integration (Brown \& Warschauer, 2006; Gao, 2005; Gao et al., 2009; Swain, 2006). The following are several recommendations to address such an issue: 1) carefully examine preservice teachers' perceptions of their success in using ICT in teaching and ascertain whether there were changes in their views and daily practices (Swain, 2006: 2) provide preservice teachers on-going guidance and scaffolding for drawing a synergy between pedagogical knowledge and technological knowledge during their school placement (Gao, Choy, Wong \& Wu, 2009), and 3) engage preservice teachers in critical reflection on the effectiveness of their instruction and students' learning (Gao, 2005; 2006; Dawson, 2006).

The third body of the literature review is about teacher reflection, which is believed to be an essential factor for constructing teachers' knowledge bases and the understanding of professional practice (Schön, 1987). Posner (2005) argued that experience with no reflection at best leads to superficial knowledge; it is the experience combined with reflection that results in professional growth. Accordingly, teacher educators and researchers have explored ways of providing on-going guidance and scaffolding for preservice teachers' reflections. Among a range of recommended strategies and approaches, analysing the video clips of preservice teacher's teaching has the potential to promote reflection (Derry, Hmelo-Silver, Nagarajan, Chernobilsky \& Beitzei, 2006). In a recent study on examining preservice teachers' perspectives of successful teaching through personalised video vignettes with limited external guidance, Calandra, Gurvitch and Lund (2008) found that the participants generally focused on themselves rather than their students, and on more technical aspects of their teaching. They emphasised the importance of providing preservice teachers a reflective framework and scaffolding for reflection.

The above literature review shows some gaps in current research about preservice teacher education on the use of ICT in classrooms. Firstly, though TPACK could be a useful lens to ascertain what preservice teachers know, there is a need to understand more about how TPK is developed and applied, and how preservice teachers' selfreflection impacts their development and translation of TPK. Secondly, there is a need to develop better scaffolding strategies to help preservice teachers develop more effective pedagogies in their field placements. One such strategy is to engage preservice teachers in scaffolded reflection on their own learning experiences and their classroom practices.

\section{Research design and methods}

Bearing the literature in mind, we designed this two-year, mixed-methods research project to fill the research gap by examining the process of preservice teachers' developing and applying TPK through self-reflection throughout their teacher preparation program. We adopted the multiple case design to investigate the learning process of a small group of preservice teachers to get an in depth understanding about their learning process.

The focus of the this paper is to present the qualitative findings about whether and how a small number of preservice teachers could draw a synergy from their espoused constructivist-orientation, TPK and reflection on their ICT use in their first year of teacher preparation to answer the two questions: 
1. How can preservice teachers develop TPK from taking an ICT course and participating in a workshop on reflection?

2. How does preservice teachers' reflection on their ICT use in their school placements impact their further development and translation of TPK into classroom teaching practice?

\section{Context of study}

The study was based on a two-year Diploma in Education (Elementary) program at the National Institute of Education, Nanyang Technological University, Singapore. Prior to the enrolment in the program, most of the preservice teachers had acquired contract teaching experience where they were required to handle a full teaching load (average 40 hours per week) to assess their suitability for the job. In the first semester of the programs while taking other educational foundation courses and curriculum courses (methods courses), all the preservice teachers at National Institute of Education take a 12-week, 2-credit core course on the pedagogical ways of using ICT for engaged learning. They learn the framework of using ICT for engaged learning and pedagogical knowledge during the first four weeks; they then learn technological knowledge about at least two ICT tools in the remaining six weeks. For the final assessment, they are required to design group projects that should effectively integrate technology into their content areas, for use in their future teaching.

Preservice teachers have two school placements: five weeks of Teaching Assistantship (the focus of the paper) after the first year of their coursework and ten weeks of Teaching Practice at the end of the second year of coursework. They are expected to use ICT during Teaching Assistantship and Teaching Practice, in line with the Singapore's ICT MasterPlan 3, which aims to "enrich and transform the learning environments of our students and equip them with the critical competencies and dispositions to succeed in a knowledge economy" (Singapore Ministry of Education, 2008). In the first two weeks of the Teaching Assistantship, preservice teachers are expected to observe their cooperating teachers' instruction. They start to handle a half teaching load (average 20 hours per week) from the third week onwards.

\section{Participants and intervention}

From a cohort of 300 preservice teachers, we purposefully selected 22 preservice teachers with a wide range of technological knowledge and skills to participate in this study. The selection was based on their self-reported technological skills indicated in the pre-ICT survey. However, eight of them opted out of the study before the start of Teaching Assistantship probably because of a fear of having an additional burden in the very demanding Teaching Assistantship. Thus, in this paper we report the qualitative findings of the remaining 14 participants whose lessons were observed and video recorded during Teaching Assistantship. The profile of these 14 are as follows: four of them rated themselves as having a high level of technological skills, seven at a medium level, and the remaining three at a low level. Ten are females and 4 are males. Ten participants major in General Education for teaching three subjects of four: English, Social Studies, Math and Science. The other four major in Chinese Language and Literature.

We conducted a two-hour intervention reflection workshop for the participants before their Teaching Assistantship. In this workshop, we firstly asked the participants to write down their definitions of reflection, and share them within the group. We then 
introduced Schön's (1987) concept of reflection in and on actions. And we explained Rolfe, Freshwater and Jasper's (2001) model of reflexive practices as a simple cycle comprising three major questions: What, So What and Now What. Under the three major questions, we listed a total of ten guiding questions to scaffold the participants' selfreflection. We finally introduced the concept of using critical incidents - anything that is meaningful - for self-reflection. We demonstrated how to choose three critical incidents for a videoed lesson.

During Teaching Assistantship, we asked the participants to answer any questions for each of the three critical incidents identified in video recorded lessons. We paired the participants up, and encouraged them to build a trust relationship. Then we asked the participants to post their answers to their selected reflection questions online so that their partners could view them and comment on their reflection. Thus, the participants were led into the scrutiny of the situation and the construction of knowledge through reflecting on/for their experiences. After Teaching Assistantship, we conducted the group discussion according to the majors: the Chinese major as one group and general education as another group. The participants in each group chose a particular incident and shared their reflections within the group.

\section{Data collection and analysis}

After getting the ethics committee approvals from the university review board, we engaged in an iterative process of data collection and analysis. We conducted three interviews, in which we asked the participants to describe their pedagogical beliefs, their beliefs in using ICT, and their past and present learning and teaching experiences if they had any. We observed and video recorded one lesson for each participant during Teaching Assistantship. Immediately after the lesson, we had an informal conversation with some participants who were available. The observation and video recording served two purposes - for the researchers' data analysis and the participants' self-reflections. We also conducted two group discussions, one after the workshop and the other after Teaching Assistantship. We kept field notes for the lesson observations and group discussions. Table 1 provides a summary of the qualitative data sources.

Table 1: Summary of the qualitative data sources

\begin{tabular}{|c|c|}
\hline $\begin{array}{l}\text { Description of activities / } \\
\text { Qualitative data sources }\end{array}$ & $\begin{array}{c}\text { First year of study } \\
\text { (August 2008 - August 2009) }\end{array}$ \\
\hline Conducting 3 interviews & $\begin{array}{l}\text { - First interview at the beginning of ICT course } \\
\text { (August 2008) } \\
\text { - Second interview completed after the ICT course } \\
\text { (December 2008) } \\
\text { - Third interview after five-week Teaching } \\
\text { Assistantship (August 2009) }\end{array}$ \\
\hline $\begin{array}{l}\text { Researchers observing and video- } \\
\text { recording the technology-based lessons }\end{array}$ & $\begin{array}{l}\text { One Teaching Assistantship lesson observation } \\
\text { between July 20-30, } 2009\end{array}$ \\
\hline Participants analysing their own teaching & August 2009 \\
\hline Group discussions & $\begin{array}{l}\text { After the workshop (May, 2009) } \\
\text { After Teaching Assistantship (August 2009) }\end{array}$ \\
\hline
\end{tabular}

Two researchers who have the expertise in qualitative research methods adopted the qualitative content analysis (Denzin \& Lincoln, 2000) to make sense of the interview data. Qualitative content analysis is appropriate for this interview data analysis 
because it produces descriptions along with the participants' expression of their views about their social worlds. After the first round of interviews, two members in the research team started a preliminary exploratory content analysis (Bogdan \& Biklin, 1992) of the interview data. Four major themes emerged: knowledge, beliefs, use of ICT, and reflection. Sub themes were developed after the second round of data analysis (See Table 2). Specifically, the two researchers used TPK as the analytic lens to analyse the data.

Table 2: Themes and subthemes of the interview data

\begin{tabular}{|l|l|}
\hline \multicolumn{1}{|c|}{ Themes } & \multicolumn{1}{c|}{ Sub themes } \\
\hline Knowledge & $\begin{array}{l}\text { Pedagogical knowledge } \\
\text { Technology knowledge } \\
\text { Pedagogical technological knowledge } \\
\text { Reflection }\end{array}$ \\
\hline Beliefs & $\begin{array}{l}\text { Pedagogical beliefs } \\
\text { Beliefs in using ICT }\end{array}$ \\
\hline Use of ICT & $\begin{array}{l}\text { Who } \\
\text { What ICT application(s) } \\
\text { Why }\end{array}$ \\
\hline Reflection & Reflection focus \\
\hline
\end{tabular}

The video data analysis also involved multiple phases. Firstly, one researcher viewed all the video data and textually described all the activities in the lesson to identify a teacher's pedagogical approaches. During this phase, the researcher paid a special attention to: how ICT was used, by whom, for what purpose, and at which specific times during the class. Secondly, the second researcher checked our descriptions with the video for accuracy. In addition, while reading through the descriptions from the video data, the two researchers identified the participants' pedagogical practices with reference to their teaching plans. The use of ICT was organised into a separate column in a spreadsheet for the later investigation on the patterns of ICT use in relation to the pedagogical practices. Thirdly, the two researchers triangulated the video data with the interview data and the other artefacts, such as lesson plans and samples of students' work. Finally, the two researchers organised the participants' ICT use into three categories: teacher use, teacher-student use and student use (which will be elaborated in the Findings) based on the kind(s) of ICT application(s), the ways and the number of teaching/learning activities in which ICT was used. As a team, we also maintained analysis memos and conducted periodic reviews of all analysed data and analytical memos.

\section{Major qualitative findings of the first-year study}

The first-year study spanned one year, from August 2008 to August 2009. The focus of this paper is to present the process by which 14 preservice teachers developed TPK from taking an ICT course, participating in an intervention workshop on reflection, and engaging in self-reflection on their ICT use during their first school placement (Teaching Assistantship). In line with the research questions, we organised the major findings into two sections: 1) developing initial TPK from the ICT coursework and workshop; and 2) impact of reflection on their ICT use for the further development and the translation of TPK. We elaborate these findings in the following two sections. 


\section{Developing initial TPK from ICT course and reflection workshop}

This section answers the first research question: How do preservice teachers develop TPK from an ICT course and intervention workshop on reflection?

The participants acknowledged that they acquired new technology skills and knowledge from their ICT course, such as how to use the interactive whiteboard (IWB), Facebook, Blog, WebQuest, Pbworks - online community building space, and Hot Potatoes - online assessment tool, and how to analyse the affordance of these applications for classroom teaching and learning. They also gained pedagogical knowledge, such as collaborative learning, project-based learning, and inquiry-based learning. Meanwhile, they registered changes in pedagogical beliefs that resonated with contemporary learning theories and in their attitudes towards using ICT for promoting meaningful learning. Their perception on the role of a teacher changed from that of a knowledge authority to a facilitator for student learning. For example, Sam, who rated himself with high technological skills, articulated the change to his pedagogical beliefs after taking the course thus:

In the past, [learning] from my own experience as a student and as a contract teacher, I expected that the teacher did all the teaching, and the students would have to do all the learning. But now I have a different concept whereby learning sometimes actually comes through contribution [from the student] and discussion [among/with students]. The role of technology has actually enabled the students to take up this position (Sam, second interview).

Accompanying the change in pedagogical beliefs, the participants also demonstrated a change in their beliefs about using ICT for teaching and learning. For example, Ted, who had low technology skills, reflected upon his change as follows:

Before coming to National Institute of Education (NIE) I never knew what ICT was all about, because during my student days, there wasn't any ICT ... but all chalk and blackboard ... At the beginning of taking the ICT course, I was scared ... Now, I think that ICT is not only [for] visual [attraction], but also for getting the students involved in active learning, to easily relate ICT to them ..." (Ted, second interview).

Tasha with low technological skills stated:

Before coming to NIE, I thought that ICT was basically more convenient for teachers to make use of various technologies to teach their lessons than for student learning ... Now, after the course, my focus is more on letting students make use of various available technologies to enhance their learning - to help them learn better and to make learning more fun and interactive (Tasha, second interview).

Additionally, the intervention workshop on reflection prior to Teaching Assistantship was beneficial to all the participants in the development of TPK. At the beginning of the workshop, the focus of their reflection tended to be on themselves as a teacher:

Reflection is the self-examination and feedback of positive and negative actions after we have taken them. The negative feedback will act as a guide for our future actions, to avoid the same mistakes. The positive feedback will also act as a guide to enhance our behaviour/action, to further improve on action needed. (Taffy)

To me, reflection means reviewing past events in terms of strengths and weaknesses, and how ICT can benefit us now and in the future. We have reflection, usually after we have experienced or observed something. (Stephanie) 
After the workshop, all participants added another dimension -- reflection in action. They also showed a shift in focus from teacher to their learners. This shift was illustrated in the following excerpt during the first group discussion after the workshop:

\begin{abstract}
Now, I begin to see that we can do reflection during the lesson so that we can improve ourselves to enhance student learning.... Reflection is value-added. We should include student performance and responses to our beliefs / actions / teaching pedagogy throughout the whole process of reflection in action, and on action. (Sam, first group discussion)
\end{abstract}

More than half of the participants, however, expressed their concerns and challenges of engaging in critical reflection in the Singapore context. As student teachers, they would encounter a conflict of interests with their cooperating teachers and school administrators. The pressure to cover the curriculum would leave them neither space nor time to change the current practices in most schools. Tasha commented:

It will be too difficult for me as a student teacher to change the situation that most teachers do not effectively use ICT for engaged learning. But I will try my best to set engaged learning as my goal of teaching with ICT. (Tasha, first group discussion).

\title{
Impact of reflection on ICT use upon further development and translation of TPK
}

This section answers the second research question: How does preservice teachers' reflection on their own ICT use in their school placement impact their further development and the translation of TPK?

All the participants used ICT for the one observed lesson during the five-week Teaching Assistantship. They used ICT across different subject areas: five English lessons, four Chinese lessons, three Science lessons, one Social Studies lesson and one Maths lesson. The 14 lessons were conducted in different settings: ten in the classrooms, two in a science laboratory, and two in a computer laboratory. The participants chose either to use one ICT tool or a suite of tools. They varied their teaching approaches from direct teaching to inquiry-based learning. Consequently, they also varied in the development of TPK. We identified three patterns: lacking the development of TPK by focusing reflection primarily on teacher's use of ICT, increasing the development of TPK by focusing reflection on both teacher and student use of ICT; and advancing the development and translation of TPK by focusing reflection on students' use of ICT, which are elaborated below.

\section{Lacking further development of TPK by focusing reflection only on teacher's use of ICT}

There were nine participants who did not use ICT in the ways that were consistent with their stated pedagogical beliefs expressed after the ICT course. They used ICT mainly as a presentation tool to complement and support their instruction rather than to prompt engaged learning from their students as they intended. They were represented by pseudonyms starting with the letter T. Regardless of possessing a varying self-rating of technology skills (high level, medium level or low level), their ICT use ranged from using one single ICT tool to complement one teaching activity to using a suite of ICT tools to support the entire teaching process. But they tended to 
share a similar pattern: being unable to synergise their pedagogical knowledge and their technological knowledge for students' learning. When focusing their reflection more on their own teaching and less on students' learning, they did not progress much further in the development of TPK. We highlighted Tasha as a case for illustration.

Table 3: Teacher's use of ICT

\begin{tabular}{|c|c|c|c|c|}
\hline $\begin{array}{c}\text { Pseudonym and } \\
\text { (technology skills) }\end{array}$ & ICT & The ways of using & Why & $\begin{array}{l}\text { Reflection } \\
\text { focus }\end{array}$ \\
\hline Tom (high) ${ }^{*}$ & Macromedia Flash & To tune in the lesson. & \multirow{3}{*}{$\begin{array}{l}\text { To } \\
\text { complement } \\
\text { one teaching } \\
\text { activity }\end{array}$} & \multirow{9}{*}{$\begin{array}{l}\text { More on } \\
\text { their own } \\
\text { teaching } \\
\text { and less on } \\
\text { student } \\
\text { learning }\end{array}$} \\
\hline Tony (medium) & Microsoft PowerPoint & To replace the textbook. & & \\
\hline Ted (low) & Microsoft PowerPoint & $\begin{array}{l}\text { To present the summary } \\
\text { of the learning points. }\end{array}$ & & \\
\hline Tinny (medium) & $\begin{array}{l}\text { Microsoft PowerPoint } \\
\text { presented on IWB }\end{array}$ & $\begin{array}{l}\text { To present the lesson } \\
\text { content. }\end{array}$ & \multirow{3}{*}{$\begin{array}{l}\text { To support } \\
\text { some } \\
\text { teaching } \\
\text { activities }\end{array}$} & \\
\hline Tamah (medium) & Microsoft PowerPoint & $\begin{array}{l}\text { To present the lesson } \\
\text { content. }\end{array}$ & & \\
\hline Taffy (medium) & $\begin{array}{l}\text { Microsoft PowerPoint } \\
\text { Ministry of Education } \\
\text { online resources }\end{array}$ & $\begin{array}{l}\text { To present the lesson } \\
\text { content. } \\
\text { To demonstrate reading. }\end{array}$ & & \\
\hline Tangia (medium) & $\begin{array}{l}\text { Microsoft PowerPoint } \\
\text { Excel }\end{array}$ & $\begin{array}{l}\text { To present the lesson } \\
\text { content. } \\
\text { To generate the graphs } \\
\text { from data. }\end{array}$ & \multirow[t]{3}{*}{$\begin{array}{l}\text { To support } \\
\text { the whole } \\
\text { teaching } \\
\text { process }\end{array}$} & \\
\hline Theresa (high) & $\begin{array}{l}\text { Microsoft PowerPoint } \\
\text { presented on IWB. } \\
\text { Macromedia Flash }\end{array}$ & $\begin{array}{l}\text { To present the lesson } \\
\text { content. } \\
\text { To simulate. }\end{array}$ & & \\
\hline Tasha* (low) & $\begin{array}{l}\text { Ministry of Education } \\
\text { online resources. } \\
\text { Microsoft PowerPoint } \\
\text { Han Shen (a Chinese } \\
\text { software). }\end{array}$ & $\begin{array}{l}\text { To demonstrate the } \\
\text { reading of the text. } \\
\text { To present the lesson } \\
\text { content. } \\
\text { To demonstrate the } \\
\text { stroke sequence of } \\
\text { Chinese characters. }\end{array}$ & & \\
\hline
\end{tabular}

* The highlighted cases

Tasha self-reported that she had a low level of technology skills. When reflecting on her use of ICT during contract teaching, she noted that: "I think that I used ICT for the purposes of convenience and time saving." (Tasha, second interview). She showed a strong intention to use ICT "...to help students learn better and to make learning more fun and interactive" (Tasha, second interview) and "...to set engaged learning as my goal of teaching with ICT" (Tasha, first group discussion). In order to achieve such a goal, she took additional effort to overcome her low technology constraint: "I approached my friend for help to insert the sound, video clips and Flash into the Microsoft PowerPoint" (Tasha, third interview).

During the observed lesson, Tasha used a suite of tools to support her instruction during the entire lesson. At the beginning of the lesson, she failed to show the Flash inserted on the Microsoft PowerPoint slides as a trigger for the lesson. But she moved on using the Ministry of Education online resources to demonstrate the reading of the text to gain her students' attention back. She illustrated the meanings of Chinese characters by using still pictures. She used Han Shen, a Chinese language software, to demonstrate the stroke sequence of Chinese characters. She used the highlighter function of the Microsoft PowerPoint application to highlight the key learning points 
and also corrected some frequently made mistakes. She ended the lesson by using a visualiser to present group activity artefacts.

Although using ICT became an integrated part of her observed lesson, Tasha did not seem to have a further development of TPK by commenting: "I have the same perceptions of using ICT to make teaching more interesting" (Tasha, third interview). This was evidenced when she explained the reason for not choosing any ICT related incidents as a critical incident for reflection:

I was very disappointed about my use of ICT. For example, the Flash did not work as expected although I had tried it out several times on my computer, and the pens of the IWB did not function well during the lesson... (Tasha, third interview).

Tasha seemed to register little change about her focus of reflection. This is reflected in the following excerpt after Teaching Assistantship:

I still think my original idea is correct, because reflection is to think what is correct, what is wrong, what needs to improve, what can be avoided on the process of teaching. It helps our teaching in future. (Tasha, third interview).

Even Tom, who had a diploma in information technology and possessed a high level of technology skills and knowledge, seemed to show more uncertainty about the translation of TPK:

I knew how to use ICT, but I don't know the principles for using ICT ... ICT is multimedia to [enhance] teaching ... The more I learn, the more confused I become. I started teaching without knowing anything (during contract teaching), then after I came to NIE, I found out that I had made lots of mistakes. One of the mistakes was to use ICT for fun rather than for engaged learning. After I corrected them during (Teaching Assistantship), I still cannot solve the problem of non-engaging my students in learning, so I am getting even more confused as a result of being unable to link theory with practice. (Tom, third interview)

\section{Increasing TPK development by focusing reflection both on teacher's and students' use of ICT}

Two participants, who rated to have a medium level of technology skills, showed a wide repertoire of instructional tactics using technologies to amplify their own teaching and their students' hands-on learning. They were represented by pseudonyms starting with the letters ST (see Table 4).

In a Primary 2 (Second Grade) English lesson on the topic of four seasons, Stacy started the lesson by using an audio recorder to play a song and used a visualiser to show the lyrics of the song. She then presented the PowerPoint slides with a lot of still pictures on the IWB. After that, she first asked some students to group pictures into one season on the IWB, and then to drag the pictures to match the season as a way of formative assessment.

Stephanie was more innovative in involving her students in using a suite of ICT tools for hands on learning activities compared with Stacy. Even before Teaching Assistantship, Stephanie seemed to begin to draw a connection between her beliefs in using ICT and pedagogical knowledge of student-centred learning. This is reflected in the following words: 
Initially I thought the role of a teacher is to teach and the role of students is to learn. But now I realise that ICT is actually a very good platform for students to be engaged in cooperative learning, in which they can actually teach themselves and other fellow students to learn... (Stephanie, second interview).

Table 4: Teacher's-and-students' use of ICT

\begin{tabular}{|l|l|l|l|l|}
\hline $\begin{array}{l}\text { Pseudonym and } \\
\text { (technology skills) }\end{array}$ & \multicolumn{1}{|c|}{ ICT } & \multicolumn{1}{|c|}{ Ways of using } & \multicolumn{1}{c|}{ Purpose } & $\begin{array}{l}\text { Focus of } \\
\text { reflection }\end{array}$ \\
\hline $\begin{array}{l}\text { Stacy } \\
\text { (medium) }\end{array}$ & $\begin{array}{l}\text { Microsoft } \\
\text { PowerPoint } \\
\text { IWB }\end{array}$ & $\begin{array}{l}\text { To present the lesson } \\
\text { content. } \\
\text { To allow students to use } \\
\text { IWB. }\end{array}$ & $\begin{array}{l}\text { To amplify their own } \\
\text { teaching. } \\
\text { To assess student } \\
\text { learning. }\end{array}$ & $\begin{array}{l}\text { Both } \\
\text { teacher's } \\
\text { instruction } \\
\text { and } \\
\text { students' } \\
\text { learning }\end{array}$ \\
\hline $\begin{array}{l}\text { Stephanie } \\
\text { (medium) }\end{array}$ & $\begin{array}{l}\text { Online video } \\
\text { clip } \\
\text { Simulation } \\
\text { Data logger } \\
\text { Online quiz }\end{array}$ & $\begin{array}{l}\text { To recap the previous } \\
\text { learning. } \\
\text { To demonstrate the } \\
\text { experiment. } \\
\text { To allow students to track } \\
\text { the change of temperature. }\end{array}$ & $\begin{array}{l}\text { teaching. } \\
\text { To provide hands on } \\
\text { learning opportunity. } \\
\text { To assess student } \\
\text { learning. }\end{array}$ & \\
\hline
\end{tabular}

Stephanie took great effort to make cooperative learning happen by planning a science practical lesson with multiple online resources and ICT tools. When she implemented the lesson, she started the first half of the lesson using Microsoft PowerPoint slides to introduce the topic, an online tutorial clip to recapitulate her students' prior knowledge, and an online Macromedia Flash simulation program to demonstrate the experiment. For the remaining part of the lesson, she arranged her students into groups and provided each group with a data logger to track the temperature change in the experiment, analyse the collected data and draw a conclusion. However, this hands on learning activity did not end smoothly because the groups of students did not start to record the temperature at the same time. She continued to carry on the lesson with an online quiz to check her students' understanding.

During the informal conversation immediately after the lesson, Stephanie revealed mixed feelings by reflecting on what she should have done better. However, she also showed a sense of satisfaction when reflecting that students had achieved her intended learning outcome as indicated in the online quiz results. In sum, Stephanie demonstrated an increase of the development of TPK when focusing her reflection both on her instruction and students' learning.

\section{Advancing the development of TPK by focusing reflection on students' use of WebQuest}

The remaining three participants, possessing either a medium or high level of technology skills, engaged their students in active learning by using ICT as a cognitive tool to extend their students' learning and knowledge construction; they were represented by pseudonyms starting with the letter S (Table 5). They stood out among the 14 participants as they entirely changed the teaching and learning environment, to one in which their students took responsibility for designing, completing an authentic task and conducting research by using a WebQuest. They tended to change their role from a knowledge authority to a facilitator for their students' knowledge construction. They demonstrated student-centric pedagogies and also showed more advanced development and adequate translation of TPK when they focused their reflection upon student's learning. 
Table 5: Student's use of WebQuest

\begin{tabular}{|c|c|c|c|}
\hline $\begin{array}{l}\text { Pseudonym and } \\
\text { (technology skills) }\end{array}$ & Other ICT tools & The ways of using & $\begin{array}{l}\text { Reflection } \\
\text { focus }\end{array}$ \\
\hline $\begin{array}{l}\text { Sophia } \\
\text { (medium) }\end{array}$ & $\begin{array}{l}\text { YouTube video. } \\
\text { Online rubric. }\end{array}$ & To tune in the lesson & \multirow[t]{3}{*}{$\begin{array}{l}\text { Student's } \\
\text { learning }\end{array}$} \\
\hline $\begin{array}{l}\begin{array}{l}\text { Sean } \\
\text { (high) }\end{array} \\
\end{array}$ & Netbooks. & To complete an authentic task & \\
\hline $\begin{array}{l}\text { Sam } \\
\text { (high) }\end{array}$ & $\begin{array}{l}\text { Online documentary video. } \\
\text { Blogpost. }\end{array}$ & $\begin{array}{l}\text { To conduct research. } \\
\text { To articulate their thinking. }\end{array}$ & \\
\hline
\end{tabular}

In an English lesson for Primary 2 (Second Grade) conducted in a computer laboratory, Sophia used a YouTube video to lead a discussion on the characteristics of a healthy diet. When she implemented the WebQuest that she and her peers designed for the university ICT course, she assigned her students to work within small groups to design a healthy and delicious lunch recipe for a newly opened school restaurant. After showing the online rubric, she asked her students to work collaboratively to prepare three Microsoft PowerPoint slides for a presentation for the next lesson.

Sean took additional effort to ask his school Technical Assistant to connect 39 netbooks to the Internet. He brought these netbooks into his classroom to engage his Primary 5 (Fifth Grade) students in an authentic learning activity. He arranged his students in pairs to complete a WebQuest activity and discuss how to compose an email and send it to him. However, Sean encountered a problem with getting Internet access for his students. Reflecting in such an unexpected incident, Sean modified his lesson plan and allowed his students to complete the assignment after class.

In a Primary 5 social studies lesson about the history of Singapore's merger and separation with Malaysia conducted in a computer laboratory, Sam also implemented a WebQuest learning activity. He made an attempt to use a suite of ICT tools to enhance student learning. For example, he used an online documentary video to "lead an emotional impact" discussion and "bring the classroom to a state of realism" (Sam, third interview). He then engaged his students in researching more about the issue in groups so that they could "use ICT as a knowledge construction tool" (Sam, third interview). Finally, he asked his students to respond to three questions in a Blogspot he created. However, some students failed to do so because the school's infrastructure could not support the mass posting. Sam could reflect in action by choosing an alternative by "just asking them to voice out their answers" (Sam, third interview). He then asked his students to post their answers onto the Blogspot after class to extend their learning beyond the four walls of the classroom. In this way, his students could learn from one another.

Sam advanced the development of TPK after focusing his reflections on student learning by commenting:

During Teaching Assistantship, I figured out what pedagogies I'm comfortable with ... I'm able to map what strategies to use, what tools to use on which type of students. So, what I've learnt about the theories and all pedagogies, I have come to practice them, and these theories have in turn become a link showing how effective my teaching is to the students ... (Sam, third interview). 


\section{Discussion and implications}

In this section, we discuss the three key findings from the qualitative data in the first year study. The first key finding is promising because the participants in our study appeared to be ready for and able to apply their technological pedagogical knowledge (TPK) for their beginning practice in their early field placements. Thus, the problem that preservice teachers are not ready to apply their technological knowledge (TK) into their classroom teaching use ICT (Kay, 2006; Russell et al., 2003; Swain, 2006) can be overcome. Our earlier study (Gao et al., 2009) that involved ten preservice teachers in Singapore found that most preservice teachers indicated their readiness in using ICT in their field placement. In that study (Gao et al., 2009), however, some of the preservice teachers chose not to use ICT during their field placement. There was a disjoint between their espoused beliefs and their practice. In this study, by making it a requirement to integrate ICT into the lessons, we provided the participants an opportunity to put into action TPK in classrooms and to further reflect upon their actions.

The second major finding aligns with the findings of another study (Gao, 2005) that learning to teach with ICT is not a linear translation of the espoused beliefs, knowledge and skills into practice, but multi-dimensional, and developmental process involving confirmation and adjustments to many aspects of changes simultaneously. These changes include espoused constructivist-orientation, and a gain in both their pedagogical and technological knowledge. These changes are, however, not merely the critical factors that influence their use of ICT in their field placements. For example, the participants with a similarly high level of technological skills and knowledge, similar pedagogical knowledge as well as similar positive beliefs chose to use a different number of ICT tools for different purposes. This finding is consistent with Fairbanks and her colleagues' (2010) argument that "knowledge alone does not lead to the kinds of thoughtful teaching we strive for" (p. 161). This implies that teacher preparation programs cannot rely solely on more ICT-related courses to promote the development of TPK. It is important to understand how preservice teachers translate their learned TPK into their field technology practices.

The third key finding highlights the importance of engaging preservice teachers in reflecting on student learning. Only those preservice teachers who demonstrated student-centric pedagogies also showed more advanced development of TPK. To a large extent, our interventions for engaging the preservice teachers in reflection had an impact in the initial development of TPK. However, simply providing a scaffolding workshop on reflection and a structure for self-reflection is not sufficient enough to influence all the preservice teachers to further develop their TPK. For example, when the participants' reflections focus on teaching effectiveness, they did not show much progress in the development of TPK. Therefore, we recommend that teacher preparation programs could engage preservice teachers to use ICT to enhance student learning, and reflect on the impact of their own experiences on their student learning. Special attention should be paid to the development of TPK as a crucial dimension of success and failure of the beginning practice.

We acknowledge two key limitations in this study. Firstly, this study is limited for not including content knowledge as an area to get a full picture of preservice teachers' development of TPACK. Secondly, there was only one lesson observation from each participant. Although as a part of the intervention, we required the participants to integrate technology into their lessons, we were cognisant of the needs of the 
participants during their field placement. Our discussion with the participants revealed concerns about using instructional approaches that might affect their performance during the field placement. As a result, the participants were agreeable to having one lesson observation involving technology integration while having the option to implement technology based lessons that would not be observed. We acknowledge that more observations are needed to get the real picture of the preservice teachers' beginning practice of using ICT and the continuous development of their TPK.

\section{Conclusion}

Our study draws new insights not only on the changes of the preservice teachers' beliefs and their development of TPK through the coursework, but also on the impact of reflection upon the development of TPK for their beginning practice in their early school placements. There was a great variation in the ways that the preservice teachers used ICT in their first field placements, as discussed in the previous section. This variation was largely related to whether the participants could synergise their constructivist-oriented beliefs, technological knowledge and pedagogical knowledge. Only the preservice teachers who demonstrated student-centric pedagogies and reflected on student learning seemed to show more advanced development of TPK. In other words, there was a correlation between the reflections of pre-service teachers' on student learning (as opposed to their teaching) and their use of ICT, such that the more the pre-service teachers were concerned with students constructing knowledge for themselves, the more they allowed students to use the technology rather than simply using ICT for demonstration purposes.

The major findings presented in this paper only provide a piece of the puzzle for nurturing preservice teachers' development of TPK. Acknowledging the limitations of small sample size (14 subjects), further studies could be conducted to investigate the impact of overtly teaching pre-service teachers how to reflect on student learning and how to facilitate student use of ICT for meaning making.We hope that our exploration will stimulate our teacher education colleagues to engage in similar investigations on how to prepare new generations of preservice teachers to be adaptive teachers for technology integration. We see the need to investigate how to provide scaffolding and feedback for preservice teachers as a form of guidance for engaging them in higher levels of reflection on their practice through building a learning community among the participants and researchers.

\section{Acknowledgments}

The work represented in this paper is funded by an educational research grant (No. OER 23/08 GP) at the National Institute of Education, Singapore. Special thanks to the preservice teachers who participated in the qualitative component of the research for their contributions.

\section{References}

Bogdan, R. \& Biklen, S. K. (1992). Qualitative research for education. Boston: Allyn and Bacon.

Brown, D. \& Warschauer, M. (2006). From the university to the elementary classroom: Students' experiences in learning to integrate technology in instruction. Journal of Technology and Teacher Education, 14(3), 599-621. http:/ / www.editlib.org/p/5996 
Bullock, D. (2004). Moving from theory to practice: An examination of the factors that preservice teachers encounter as the attempt to gain experience teaching with technology during field placement experiences. Journal of Technology and Teacher Education, 12(2), 211-237. http: / / www.editlib.org/p/12783

Calandra, B., Gurvitch, R. \& Lund, J. (2008). An exploratory study of digital video editing as a tool for teacher preparation. Journal of Technology and Teacher Education, 16(2), 137-153. http:/ / www.editlib.org/p/23496

Dawson, K. (2006). Teacher inquiry: A vehicle to merge prospective teachers' experience and reflection during curriculum-based, technology-enhanced field experiences. Journal of Research on Technology in Education, 38(3), 265-292. http:/ / www.eric.ed.gov/ERICWeb Portal / contentdelivery / servlet / ERICServlet?accno=EJ728905

Denzin, N. K. \& Lincoln, Y. S. (Eds.) (2000). Handbook of qualitative research (2nd ed.). Thousand Oaks, California: Sage Publications, Inc.

Derry, S. J., Hmelo-Silver, C. E., Nagarajan, A., Chernobilsky, E. \& Beitzel, B. D. (2006). Cognitive transfer revisited: Can we exploit new media to solve old problems on a large scale? Journal of Educational Computing Research, 35(2), 145-162. http: / / dx.doi.org/10.2190/ 0576-R724-T1495432

Fairbanks, C. M., Duffy, G. G., Faircloth, B. S., He, Y., Levin, B., Rohr, J. \& Stein, C. (2010). Beyond knowledge: Exploring why some teachers are more thoughtfully adaptive than others. Journal of Teacher Education, 62(1-2), 161-171. http: / / dx.doi.org/10.1177/0022487109347874

Finger, G., Jamieson-Proctor, R. \& Albion, P. (2010). Beyond pedagogical content knowledge: The importance of TPACK for informing preservice teacher education in Australia. In M. Turcanyis-Szabo \& N. Reynolds (Eds.), Key competencies in the knowledge society (pp. 114-125). Berlin, Heidelberg: Springer.

Gao, P. (2005). Learning to teach with information technology: Preservice teachers' perspectives and experiences across their three semester preparation. Dissertation Abstracts International, 66(10), 3550. (UMI No. 3194016). http:/ / surface.syr.edu/tl_etd/33

Gao, P. (2006). Teaching with technology: Creating constructivist classrooms. In M. S. Khine (Ed.), Teaching with technology: Strategies for engaging learners, pp. 21-48. Singapore: Prentice Hall.

Gao, P., Choy, D., Wong, A. F. L., \& Wu, J. (2009). Developing a better understanding of technology based pedagogy. Australasian Journal of Educational Technology, 25(5), 714-730. http:/ / www.ascilite.org.au/ajet/ajet25/gao.html

Gao, P., Wong, A. F. L., Choy, D. \& Wu, J. (2010). Developing leadership potential for technology integration: Perspectives of three beginning teachers. Australasian Journal of Educational Technology, 26(5), 643-658. http:/ / www.ascilite.org.au/ajet/ajet26/gao.html

Harris, J., Mishra, P. \& Koehler, M. (2009). Teachers' technological pedagogical content knowledge and learning activity types: Curriculum-based technology integration reframed. Journal of Research on Technology in Education, 41(4), 393-417. http:/ / www.iste.org/learn/ pub lications / journals/jrte-issues/Teachers_Technological_Pedagogical_Content_Knowledge_ and_Learning_Activity_Types_Curriculum-based_Technology_Integration_Reframed.aspx

Hughes, J., Thomas, R. \& Scharber, C. (2006). Assessing technology integration: The RAT replacement, amplification, and transformation - framework. In C. Crawford et al. (Eds.), Proceedings of Society for Information Technology \& Teacher Education International Conference 2006 (pp. 1616-1620). http:/ / www.editlib.org/p/ 22293

Jonassen, D. H., Peck, K. \& Wilson, B. G. (1999). Learning with technology: A constructivist approach. Upper Saddle River, NJ: Prentice-Hall. 
Kay, R. H. (2006). Evaluating strategies used to incorporate technology into preservice education: A review of the literature. Journal of Research on Technology in Education, 38(4), 383408. http:/ / www.eric.ed.gov / ERICWebPortal/ contentdelivery/ servlet/ERICServlet? accno $=\mathrm{EJ} 768720$

Koh, J. H. L., Chai, C. S. \& Tsai, C. C. (2010). Examining the technological pedagogical content knowledge of Singapore preservice teachers with a large-scale survey. Journal of Computer Assisted Learning, 26(6), 563-573. http: / / dx.doi.org/10.1111/j.1365-2729.2010.00372.x

Lim, C. P. \& Chai, C. S. (2008). Teachers' pedagogical beliefs and their planning and conduct of computer-mediated classroom lessons. British Journal of Educational Technology, 39(5), 807-828. http:/ / dx.doi.org/10.1111/j.1467-8535.2007.00774.x

Maddux, C., LaMont Johnson, D. \& Willis, J. (2001). Educational computing: Learning with tomorrow's technologies (3rd ed.). Needham Heights, MA: Allyn \& Bacon.

Mishra, P. \& Koehler, M. (2006). Technological pedagogical content knowledge: A framework for teacher knowledge. Teachers College Record, 108(6), 1017-1054. http: / / www.tcrecord.org/Content.asp?ContentId=12516

Niess, M. L. (2005). Preparing teachers to teach science and mathematics with technology: Developing a technology pedagogical content knowledge. Teaching and Teacher Education, 21, 509-523. http:/ / dx.doi.org/10.1016/j.tate.2005.03.006

Onwuenghuzie, A. \& Teddlie, C. (2003). A framework for analyzing data in mixed methods research. In A. Tashakkori \& C. Teddlie (Eds.), Handbook of mixed methods in social and behavioral research (pp. 351-384). Thousand Oaks, CA: Sage Publications.

Posner, G. J. (2005). Field experiences: A guide to reflective teaching (6th ed.). New York: Allyn and Bacon.

Rolfe, G., Freshwater, D. \& Jasper, M. (2001). Critical reflection for nurses and the caring professions: A user's guide. Basingstoke: Palgrave.

Russell, M., Bebell, D., O'Dwyer, L. \& O'Connor, K. (2003). Examining teacher technology use: Implications for preservice and inservice teacher preparation. Journal of Teacher Education, 54(4), 297-310. http:/ / www.highbeam.com/doc/1G1-108194321.html

Schmidt, A., Evrim, B., Thompson, A. D., Mishra, P., Koehler, M. J. \& Shin, T. E. (2009). Technological Pedagogical Content Knowledge (TPACK): The development and validation of an assessment instrument for preservice teachers. Journal of Research on Technology in Education, 42(2), 123-149. http: / / www.eric.ed.gov/ ERICWebPortal/ contentdelivery / servlet/ERICServlet?accno=EJ868626

Schön, D. A. (1987). Educating the reflective practitioner: Toward a new design for teaching and learning in the professions. San Francisco: Jossey-Bass.

Shulman, L. S. (1987). Knowledge and teaching: Foundations of the new reform. Harvard Educational Review, 57(1), 1-23.

Singapore Ministry of Education (2008). MOE Launches third Masterplan for ICT in education. Press release 5 August. [viewed 10 May 2010, verified 9 Sep 2011]

http: / / www.moe.gov.sg/media/press / 2008/08/moe-launches-third-masterplan.php

Swain, C. (2006). Preserviceteachers self-assessment using technology: Determining what is worthwhile and looking for changes in daily teaching and learning practices. Journal of Technology and Teacher Education, 14(1), 29-59. http: / / www.editlib.org/p/5089 
Thompson, A., Schmidt, D. \& Davis, N. (2003). Technology collaboratives for simultaneous renewal in teacher education. Educational Technology Research and Development, 51(1), 73-89. http:/ / www.aect.org/intranet/ publications/etrd/5101.asp

US Department of Education (2006). Preparing tomorrow's teachers to use technology (PT3). Archived information. [viewed 10 May 2009, verified 9 Sep 2011] http: / / www2.ed.gov/ programs/teachtech/index.html

Vannatta, R., Beyerbach, B. \& Walsh, C. (2001). From teaching technology to using technology to enhance student learning: Preservice teachers' changing perceptions of technology infusion. Journal of Technology and Teacher Education, 9(1), 105-127. http:// www.editlib.org/p/8456

Authors: Dr Ping Gao (corresponding author), Associate Professor, is with Curriculum and Instruction at the College of Education, University of Northern Iowa, USA. She was with the Learning Sciences and Technologies Academic Group at the National Institute of Education, Nanyang Technological University, Singapore when the study was undertaken. Her research interests include teacher learning, technology integration, program evaluation, and qualitative research. Email: ping.gao@uni.edu

Dr Seng Chee Tan, Associate Professor, is with the Learning Science and Technologies Academic Group at the National Institute of Education, Nanyang Technological University, Singapore. His research interests include computer-supported collaborative learning, constructivist learning environment, learning communities and computers as cognitive tools. Email: sengchee.tan@nie.edu.sg

Mr Longlong Wang, Research Associate, is with the Learning Sciences and Technologies Lab, at the National Institute of Education, Nanyang Technological University, Singapore. His research interests include discourse analysis and social linguistics. Email: longlong.wang@nie.edu.sg

Dr Angela F. L. Wong, Associate Professor, is with the Learning Sciences and Technologies Academic Group, National Institute of Education, Nanyang Technological University, Singapore. She lectures in instructional technology and educational psychology courses. Her research interests include learning environments, instructional technology and teacher education. Email: angela.wong@nie.edu.sg

Dr Doris Choy, Assistant Professor, is with the Learning Sciences and Technologies Academic Group at the National Institute of Education, Nanyang Technological University, Singapore. Her areas of research include: teacher education, integration of information and communication technology in schools, teacher education and designing and managing instructional design projects. Email: doris.choy@nie.edu.sg

Please cite as: Gao, P., Tan, S. C., Wang, L., Wong, A. \& Choy, D. (2011). Self reflection and preservice teachers' technological pedagogical knowledge: Promoting earlier adoption of student-centred pedagogies. Australasian Journal of Educational Technology, 27(6), 997-1013. http: / / www.ascilite.org.au/ajet/ ajet27/gao.html 